\section{Risk Management in Born Globals: the Case of Brazilian Craft Breweries}

\author{
Fabricio Stocker ${ }^{1,+}$ \\ ${ }^{1}$ Universidade de São Paulo, São Paulo, SP, Brazil \\ Gustavo Abib ${ }^{2, \Omega}$ (D) \\ ${ }^{2}$ Universidade Federal do Paraná, Curitiba, PR, Brazil
}

\section{ABSTRACT}

This work analyzes how risk management occurs in the internationalization process of Brazilian born global companies. Accordingly, we adopted the qualitative research approach, used a multiple case study strategy, and selected seven relevant craft breweries with national prominence. The findings highlight how risks are perceived in the internationalization process by managers and classified among commercial, intercultural, monetary and country risks. We also identified that these enterprises use different actions to mitigate risks, such as planning, market research, and building scenarios. The contributions discussed in this study are the identification of factors such as the international background of managers and the use of networks to minimize the perception of risk. Additionally, we discussed the ways in which risks are perceived and how the different mitigation strategies work. Finally, we proposed an integrated risk management model for the internationalization of born globals.

Keywords: Risk Perception; New Ventures; Internationalization; Born Global; Craft Breweries.

\section{INTRODUCTION}

The recent expansion of markets and the use of internationalization strategies are characteristic of the globalization phenomenon and the complexity of the global market. International companies, such as those studied by Bartlett and Ghoshal (2000), are driven by the demand for resources in different localities and have started a chain of multinationalization by crossing national frontiers and exploring new scenarios, thus increasing export and import incentives and investments from abroad.

However, the vulnerability of connected markets, economic instabilities, and global crises has aroused the attention of managers to issues such as risk phenomena in the strategic processes of organizations (Frigo, 2009). This risk assessment and the actions and strategies developed through the risk management process seem to be influenced by the characteristics of the entrepreneur, the resources available to achieve the internationalization objectives and the environment in which the company is inserted (Liesch, Welch, \& Buckley, 2011).

Due to the internationalization of markets, the growing presence of companies and professionals with international experiences and the
Corresponding author:

† Universidade de São Paulo, São Paulo, SP, Brazil

E-mail: fabriciostocker@usp.br

${ }^{\Omega}$ Universidade Federal do Paraná, Curitiba, PR, Brazil

E-mail: gustavo.abib@gmail.com

Received: 01/23/2018.

Revised: 05/04/2018.

Accepted: 07/30/2018.

Published Online: 05/15/2019.

DOI: http://dx.doi.org/10.15728/bbr.2019.16.4.2 
strengthening of networks around the world, the environmental changes in international trade have driven the emergence of new ventures with foreign operations and global visions. Since the beginning, the born globals have been investigated by several authors, such as Knight and Cavusgil (2004), Oviatt and McDougall (2005), Weerawardena, Mort, Liesch and Knight (2007), Gabrielsson, Kirpalani, Dimitratos, Solberg and Zucchella (2008), Dib, Rocha and Silva (2010), Trudgen and Freeman (2014), Dimitratos, Johnson, Plakoyiannaki and Young (2016), Cahen, Oliveira and Borini (2017), and Dzikowski (2018).

The specific characteristics of born globals indicate that the way that risks are perceived and managed differs from other kinds of companies. This difference is the result of a different and not a gradual process of internationalization, as discussed in the international business literature (Gabrielsson, Kirpalani, Dimitratos, Solberg, \& Zucchella, 2008; Kubíčková, Tuzová, \& Toulová, 2016; Sozuer, Altuntas, \& Semercioz, 2017; Grazzi \& Moschella, 2018). For this reason, we believe that this issue is configured as a potential research topic that can produce useful outputs for managerial applications and expand theoretical boundaries.

It is recognized that there is a necessity to explore how born globals' skills and abilities could influence the mitigation of global risks. Moreover, one must explore how the research can reconcile the divergent views between the prevailing theories of international business and develop new propositions based on the empirical findings (Knight \& Liesch, 2015).

Considering the topics discussed above, the objective of this research is to analyze how risk management occurs in the Brazilian born globals' internationalization process. Therefore, the main objective of this study is divided into two specific objectives: a) to describe the risk factors perceived in the internationalization by the entrepreneurs of the studied companies and b) verify the actions and strategies regarding risk management in the internationalization process of born global companies.

\section{THEORETICAL BACKGROUND}

\subsection{INTERNATIONALIZATION PROCESS AND BORN GLOBALS}

The internationalization process encompasses some uncertainties and risks that demand a significant amount of information to understand the situation for all sizes of companies. However, especially in small and medium-sized companies, managers are not able to predict all the risks that will be faced during the internationalization process (Kubíčková \& Toulová, 2013). Sometimes, this lack of perception about specific risks affects the process and increases the costs of the international operation (Rodriguez, Boats, \& Alvarez, 2010; Boso, Oghazi, \& Hultman, 2017).

Participation in international business may involve different kinds of risks, such as those associated with the choice of geographical location, the existence of different economic situations, and the political and governmental aspects of the country. Additional issues are related to the market, the specific public, and risks associated with the organization itself (Kubíčková, Tuzová, \& Toulová, 2016; Rahman, Uddin, \& Lodorfos, 2017).

In the early stages of internationalization, many companies are faced with a lack of information and knowledge about foreign markets, thus accentuating the perception of risk and uncertainty (Cortezia \& Souza, 2011; Grazzi \& Moschella, 2018). This information bundle is important in decision-making at various levels of international activities, but especially in engaging in new activities, such as the introduction of new markets, using different modes of operation, or developing global strategies (Liesch, Well, \& Buckley, 2011; Hânell, Nordman, \& Tolstoy, 2017).

In the international business literature, the importance of risk study is recognized, although it has been treated superficially and has been filled with studies directed at political and 
BBR

16,4

exchange risks (Kubičková \& Toulová, 2013; Nunes, 2016). In economic-based theories on internationalization, such as Product Cycle Theory (Vernon, 1966), Market Power Theory (Hymer, 1976), Internationalization Theory (Buckley \& Casson, 1976) and Theory of the Eclectic Paradigm (Dunning, 1979), the strategies and decisions for internationalization are strongly related to the risks and the commercial, monetary and political issues of the countries where international expansion will take place.

Therefore, it is clear that there is a more significant concern with the risks of interculturality that are related to cultural differences and the psychic distance evidenced by the studies of the Uppsala Model (Johanson \& Vahlne, 1977) and Network Approach in International Business (Andersson, Johanson, \& Vahlne, 1997) than that with the economics theories.

According to Gabrielsson et al. (2008), the born global companies are those companies with a global vision of their foundation and with products and services with global potential for the acceleration of the internationalization process. It is assumed that these companies should have a higher propensity for risk when dealing with a higher speed of internationalization in a short period. This same view is shared by authors in the area, such as Autio (2017), Choquette, Rask, Sala and Schröder (2017) and Grazzi and Moschella (2018).

Regarding risk in born global companies risk, Dib, Rocha and Silva (2010) state that the smaller the size of the enterprise, the higher the flexibility and the propensity for it to face international risks. Moreover, regarding the company's performance, the younger companies had lower risk aversion in the global environment (Jin, Jung, \& Jeong, 2018).

The Uppsala model by Johanson and Vahlne that deals with uncertainty refers to the contingency of uncertainty caused by the lack of knowledge and experience in the international market, albeit without a distinction between risk and uncertainty. However, Figueira-de-Lemos, Johanson and Vahlne (2011) acknowledge that the intention of the uncertainty discussion proposed by the model is related to the concept of risk presented by March and Shapira (1987). The risk is the significance of undesirable result due to sources of uncertainty derived from external (environmental) or internal (own organizational) factors.

Another convergent definition refers to what Sitkin and Weigart (1995) affirmed in conceptualizing risk as the uncertainty and the potentially significant or negative results. Accordingly, when the decision has some degree of difficulty and the effects are unknown, the choice is characterized as risky.

For this research, we adopted the international business risk classification presented by Cavulsgil, Knight and Riesenberger (2010). This model states that the internationalization process is composed of four main types of risk: commercial risk, financial risk, country risk and intercultural risk. In this classification, the authors listed as inherent to commercial risk: the fragility of the partners, the competitive intensity, and operational and strategic problems. Financial risks include questions about assets, foreign taxation, prices, inflation and monetary exposure. Country risk refers to governmental, social and political issues. Finally, cultural risk includes the ethical, cultural and the decision-making and management styles of the companies present in the country.

According to Nunes (2016), the risks involved in international business are not controllable and unavoidable; however, through their perception and evaluation, Kubíčková, Tuzová and Toulová (2016) affirm that managers can direct actions to mitigate their effects.

\subsection{Perception ANd RiSK MANAgemient In INTERNATIONALIZATION}

Most risk studies use the concept of risk perception proposed by Sitkin and Weingart (1995). The concept of risk perception refers to the assessment of the level of risk that is inherent in a situation. It is associated with its uncertainty and the control that individuals have over possible outcomes. 
According to Acedo and Jones (2007), the perception of risk is related to the individual's international orientation, their level of knowledge, international personal and professional experiences, level of education and ability with foreign languages. Furthermore, this international orientation can be accentuated with the participation in travel, courses, hiring specialized personnel, and development of new experiences, through which the perception of risk can be reduced.

Frigo and Anderson (2011) define that risk management is a process for identifying, assessing and managing risks with the primary goal of protecting and creating value for the company. Its purpose is to evaluate internal and external events and to plan how these scenarios may affect the organization's ability to achieve its objectives. According to the authors, strategic risk management is an ongoing process and must be intertwined with the organization's decision-making strategies and methods.

Thus, when entrepreneurs perceive lower risks in foreign activities, the company becomes more committed to these operations abroad and advances in the phases of the internationalization process (Acedo \& Florin, 2006). It is not for managers and entrepreneurs to merely identify and accept the risks that may be exposed in international activities, but they need to act and manage them to mitigate their possible impacts on the company's performance and results (Oviatt, Shrader, \& McDougall, 2004; Jin, Jung, \& Jeong, 2018).

Although risk seems to be present in international business discussions, few studies have focused on risk management in the internationalization process (Figueira-de-Lemos, Johanson, \& Vahlne, 2011; Kubíčková \& Toulová, 2013; Knight \& Liesch, 2015; Dimitratos et al., 2016).

According to Dimitratos et al. (2016), the perception of risk is closely related to the characteristics and attributes of the business manager and is evidenced in critical decisions, as in the case of internationalization. However, this risk propensity, which is treated by Grichnik (2008) as a trait of the manager's personality, is an influential but not decisive factor in decision-making, although some studies have been addressing risk-taking behaviors as an explanatory variable for the international performance of born globals (Jin, Jung, \& Jeong, 2018).

Along with this view of the entrepreneur-manager of the business, the assessment of the risk level is also profoundly influenced by the industry and the target market (Acedo \& Florin, 2006; Jin, Jung, \& Jeong, 2018). The way that the risk is perceived also affects the actions and decisions regarding its management (Dib, Rocha, \& Silva, 2010).

In organizations, mainly small and medium-sized enterprises (SMEs), due to the lack of financial resources, time or trained personnel, risk management is ignored, and the risks are assessed as predominantly intuitive and based on the managers' experiences (Kubíčková, Votoupalová, \& Toulová, 2014). However, as the authors point out, this concern with how the risks are perceived and managed makes a difference in the development of business strategies and the results that are expected by the organization.

Oviatt, Shrader and McDougall (2004) indicate that risk management is found in the internationalization literature with the intention of exploring how inherent risks to foreign operations are managed by its managers in new international ventures. Thus, it is not simple for managers and entrepreneurs to identify and accept the risks that may be exposed in international activities, but they need to act and manage them to mitigate their possible impacts on the company's performance and results (Oviatt, Shrader, \& McDougall, 2004).

The risks involved in international business are often related to the fact that companies venture into the unknown where the lack of market knowledge can often result in wasted resources, time and investments (Frigo \& Anderson, 2011). The importance of actions related to the environmental analysis, the sector and the internal capabilities of the company for better risk management becomes evident (Grazzi \& Moschella, 2018). 
Oviatt, Shrader and McDougall (2004), when addressing risk management, developed a risk management model for the internationalization of new ventures. This model establishes useful propositions regarding the analyses and influences of the environment, industry conditions, personal characteristics of entrepreneurs, issues related to the enterprise itself and its internationalization process regarding risk management.

According to the authors, the proposed model is based on Miller's (1992) integrated risk management concept, which had already emphasized the importance of managing three different risk groups: (1) the general environmental risks, (2) the risks related to the industry / segment and (3) the specific risks of the enterprise. The significant distinction brought by the model proposed by Oviatt, Shrader and McDougall (2004), besides being focused on new international ventures, is the specification of the mediation and influence between the different groupings when determining the level of risk.

In the model, the personal characteristics, which are evidenced by the psychological traits and the relationship networks, influence the way in which the entrepreneurs interpret the conditions of the industry. These interpretations affect the decisions they make about their ventures, including how risks are managed.

In addition to the vision presented, the risk factors in international business are analyzed according to the manager's perception of these potential risks and how the management team and the company will develop actions to manage or mitigate perceived risks in the internationalization process (Leite \& Moraes, 2014).In this sense, when considering the phases of analysis and the identification and classification of risks, the process indicates the possible reasoning for the mitigation and development of actions against the risks perceived in the internationalization process (Figueira-de-Lemos, Johanson, \& Vahlne, 2011).These activities were essential for the sustainability of the business in the international market (Jin, Jung, \& Jeong, 2018).

\section{METHODOLOGICAL PROCEDURES}

Based on the purpose of analyzing the risk management in the internationalization process of born global companies, we conducted an exploratory qualitative research. For this qualitative research, we adopted a multi-case study research strategy (Eisenhardt, 1989).

Regarding the cases chosen, considering that the object of study is different born global companies, we used some criteria for the cases' choice and selection. The sector of the study was the Beverage Industry, specifically the beer market, which is highly competitive in Brazil. Some additional criteria were the type of organization (craft breweries that were born globals, which grew by $570 \%$ in the last ten years) and other features such as the year of foundation (up to seven years of foundation), international business (with design or process internationalization since the foundation) and awards (national and international). This classification showed the relevance of the cases for the study in the sector.

After the setup of the criteria, we selected seven craft breweries to conduct the research, and nine semi-structured interviews were held. We conducted the interviews with their founders and directors, who are the primary decision-makers in the company and those responsible for the internationalization process.

This study started with documented research (with internal documents and secondary data), semi-structured interviews and non-participant observations (in beer events and the companies studied). As a method to analyze the data collected, we used content analysis, according to Bardin (2006). Table 1 below shows the companies and their respondents.

Prior to the six months of data collection between June and November of 2016, the researcher approached the field of study for the purposes of the observation and selection of the cases to be studied. During the period of definition of the sector of study and the 
Table 1 - Identification of companies and survey respondents

\begin{tabular}{|c|c|c|c|c|}
\hline Company & Interviewee / Position & Interviewee Code & Date & $\begin{array}{l}\text { Duration } \\
\text { (minutes) }\end{array}$ \\
\hline \multirow{3}{*}{$\begin{array}{l}\text { Cervejaria } \\
\text { Bodebrown (Pilot } \\
\text { case) }\end{array}$} & Managing Partner (founder) & Interviewee 1 & $7 / 15 / 16$ & (Not recorded) \\
\hline & and Brewmaster & & & \\
\hline & Commercial director & Interviewee 2 & $7 / 15 / 16$ & (Not recorded) \\
\hline $\begin{array}{l}\text { Cervejaria } \\
\text { Tupiniquim }\end{array}$ & $\begin{array}{l}\text { Proprietary Partner (founder) } \\
\text { and Commercial Director }\end{array}$ & Interviewee 3 & $8 / 30 / 16$ & 55 \\
\hline $\begin{array}{l}\text { Seasons Craft } \\
\text { Brewery }\end{array}$ & $\begin{array}{l}\text { Managing Partner (founder) } \\
\text { and Brewmaster }\end{array}$ & Interviewee 4 & $8 / 31 / 16$ & 60 \\
\hline Irmãos Ferraro & $\begin{array}{l}\text { Managing Partner (founder) } \\
\text { and Brewmaster }\end{array}$ & Interviewee 5 & $8 / 31 / 16$ & 50 \\
\hline $\begin{array}{l}\text { Baldhead Craft } \\
\text { Beers }\end{array}$ & $\begin{array}{l}\text { Managing Partner (founder) } \\
\text { and Brewmaster }\end{array}$ & Interviewee 6 & $09 / 01 / 2016$ & 56 \\
\hline Sebrae RS & $\begin{array}{l}\text { Project Manager "Pólo } \\
\text { Cervejeiro" }\end{array}$ & Interviewee 7 & $09 / 02 / 2016$ & 65 \\
\hline Way Beer & $\begin{array}{l}\text { Proprietary Partner (founder) } \\
\text { and Commercial Director }\end{array}$ & Interviewee 8 & $11 / 28 / 16$ & 60 \\
\hline Bastards Brewery & $\begin{array}{l}\text { Managing Partner (founder) } \\
\text { and Brewmaster }\end{array}$ & Interviewee 9 & $11 / 29 / 16$ & 50 \\
\hline
\end{tabular}

Source: Elaborated by the Authors (2018).

preliminary brewery sector survey of information, the researcher attended the following events: 1) the Brazilian Beer Festival and the Brazilian Beer Competition of Blumenau - Santa Catarina, 2) the South Beer Cup in Curitiba - Paraná, and 3) the Malt industry of the Agricultural Agroindustrial Cooperative - Paraná. The observations and approach to the field were essential for access to the entrepreneurs studied and to define the guiding questions of the semi-structured interviews.

According to MAPA - the Ministry of Agriculture, Livestock and Supply of the Federal Government, by the end of 2017, 679 craft breweries were registered in Brazil. Among these, some breweries with an even shorter market operation time already had the intention or are in the process of internationalization. This process can include direct or indirect production, partnerships and strategic alliances for production and distribution, and outsourcing and the import of products, among other internationalization strategies.

Considering that the focus of this research is born global companies and the decision was made to investigate the craft brewery segment, the criteria for selecting the cases were the year that the company was founded, the beginning of the international activities and the awards received, as presented in Table 2.

In this methodological process, some criteria were followed for the research to achieve validity and reliability (Miles \& Huberman, 1994). For the reliability issues, this study adopted the study protocol that was elaborated before going to the field and collecting data. We used field diaries for recording and confirming the activities performed in companies, and key informants were used to review the points raised in the exploratory phase of the research. Additionally, we conducted the analysis of the database through the Atlas.ti software, which corroborates the validity and reliability of the study.

In the process of refining the instrument of data collection and the identification of the units of analysis, a pilot case study was developed (Case 1). Accordingly, the choice of the case followed the same criteria of the research. Following the procedures of data collection and the preliminary analysis of the data, it showed congruence with the objectives of the research and the data expected for analysis. Therefore, the pilot case was integrated into the base of the survey data. This procedure is applied in qualitative case studies with the aim 
Table 2 - Presentation of the selection criteria

\begin{tabular}{|c|c|c|c|c|}
\hline Case & Awards & Founded in & Beginning of Internat. & International Activity \\
\hline 1 & $\begin{array}{l}\text { Gold Medal at the Mondial } \\
\text { de La Biére in Belgium, Best } \\
\text { Brewery of the Year by the } \\
\text { Brazilian Beer Competition, } \\
\text { Best Brewery in Brazil by } \\
\text { Ratebeer Rankings (US) } \\
\text { Four Gold Medals at La } \\
\text { BiérMondial, and Australian } \\
\text { International Beer Awards. }\end{array}$ & 2009 & 2013 & $\begin{array}{l}\text { Collaborative } \\
\text { Production, } \\
\text { Imports, Exports } \\
\text { and Distribution. } \\
\text { Countries: USA, } \\
\text { Canada, France, } \\
\text { Australia, United } \\
\text { Kingdom, Italy, and } \\
\text { Belgium }\end{array}$ \\
\hline 2 & $\begin{array}{c}\text { Award at the South BeerCup } \\
\text { Festival, Brazil's Best } \\
\text { Brewery for Ratebeer } \\
\text { Rankings (USA), Awards } \\
\text { at the Brazilian Beer } \\
\text { Competition, and Copenhagen } \\
\text { BeerCelebration Special } \\
\text { Guest. }\end{array}$ & 2010 & 2012 & $\begin{array}{c}\text { Collaborative } \\
\text { production, Strategic } \\
\text { Alliances and Exports. } \\
\text { Countries: USA, } \\
\text { Scotland, Canada, and } \\
\text { Denmark }\end{array}$ \\
\hline 3 & $\begin{array}{c}\text { Gold Medal at La } \\
\text { Bière'sMondial Festival, } \\
\text { Second Best Beer of the } \\
\text { Year at the Brazilian Beer } \\
\text { Competition, and Top of } \\
\text { Marketing by ADVM - Brazil. }\end{array}$ & 2013 & --- & $\begin{array}{l}\text { Internationalization } \\
\text { Project for USA. }\end{array}$ \\
\hline 4 & $\begin{array}{l}\text { Best Brewery of the Year by } \\
\text { South BeerCup, Best Brewery } \\
\text { of the Year by the Brazilian } \\
\text { Beer Competition, Platinum } \\
\text { Medal at La Bière'sMondial } \\
\text { Festival, and Brazil's Best } \\
\text { Beer by Ratebeer Rankings } \\
\text { (USA). }\end{array}$ & 2013 & 2014 & $\begin{array}{c}\text { Imports, Collaborative } \\
\text { Production, Strategic } \\
\text { Alliances and Exports. } \\
\text { Countries: USA, } \\
\text { Denmark, Sweden, } \\
\text { Western Europe and } \\
\text { Scandinavia }\end{array}$ \\
\hline 5 & $\begin{array}{l}\text { Awards in the Brazilian Beer } \\
\text { Competition, and Gold Medal } \\
\text { at the South BeerCup Festival }\end{array}$ & 2010 & 2014 & $\begin{array}{l}\text { Collaborative } \\
\text { productions and } \\
\text { Strategic Alliances. } \\
\text { USA and Germany. }\end{array}$ \\
\hline 6 & $\begin{array}{l}\text { Awards in the Brazilian Beer } \\
\text { Competition }\end{array}$ & 2011 & --- & $\begin{array}{l}\text { Internationalization } \\
\text { project for England. }\end{array}$ \\
\hline 7 & $\begin{array}{c}\text { Awards in the Brazilian Beer } \\
\text { Competition }\end{array}$ & 2009 & --- & $\begin{array}{l}\text { Internationalization } \\
\text { project. }\end{array}$ \\
\hline
\end{tabular}

e La Biére in Belgium, Bes

Production,

Brewery of the Year by the

Ratebeer Rankings (US)

Australia, United

BiérMondial, and Australian

Belgium

ward at the South BeerCup

Collaborative

production, Strategic

Counties: USA,

Rankings (USA), Awards

petition, and Copenhagen

Scotland, Canada, and

Denmark

Guest.

\section{Gold Medal at La}

Bière'sMondial Festival,

Year at the Brazilian Beer

Best Brewery of the Year by

outh BeerCup, Best Brewery

of the Year by the Brazilian

Beer Competition, Platinum

Festival, and Brazil's Best

(USA).

Source: Elaborated by the Authors (2018).
Imports, Collaborative

Production, Strategic

Countries: USA,

Denmark, Sweden,

Scandinavia

Collaborative

productions and

Strategic Alliances USA and Germany.

project.

for greater validity in a study, with respect to the research process and the analysis of the data collected.

We used the Atlas.ti software to analyze the data since a large volume of textual data was collected. For this purpose, we created a hermeneutic unit in which the whole process of data codification and analysis was concentrated. Therefore, the interviews were recorded. Except for the pilot case where notes and field records were made, all of them were transcribed and transferred to Atlas.ti. Thereafter, we used the codes to map the reports that were considered essential and to capture their meanings for the achievement of the proposed objectives, as evidenced in Table 3. 
Table 3 - Description of the data codification

\begin{tabular}{lllll}
\hline Family & Code & Family & Code & \\
\hline \multirow{3}{*}{ Born global } & Entrepreneur & & Commercial Risk & \multirow{2}{*}{ Risk Perception } \\
& Organization & \multirow{2}{*}{ Risks } & Intercultural Risk & \\
& Environment & & Monetary Risk & Risk \\
& Born Global & & Country Risk & Management \\
\hline
\end{tabular}

Source: Elaborated by the Authors (2018).

After coding the data and reviewing the interview transcripts and the other data that were collected, the Atlas.ti software generated reports. We analyzed the results based on the reports with the coded data.

According to Eisenhardt (1989), regarding the validity and reliability, the logical coherence of the scientific study can be evidenced by the consistency of the relations between the research problem, the definition of the objectives, the choice of the literature and the methodological procedures that were chosen. Thus, we created the theoretical and methodological mooring matrix of the research based on Telles's (2001) indications to identify in a clear and synthetic way the analytical categories related to the research problem, the general and specific objectives and the guiding questions of the research. We also based on Telles the constitutive definitions, the sources of the evidence, the data collection techniques and the base literature for data analysis.

To sum up, the methodological steps of this research design are outlined in Table 4.

Table 4 - Research Design

\begin{tabular}{ll}
\hline Category & Decision \\
\hline Classification & Qualitative \\
Objective & Exploratory \\
Purpose & Applied Research \\
Environment & Field Search \\
Temporal Design & Cross section with longitudinal approach \\
Research strategy & Multiple case study \\
Collection Techniques & Documentary research, semi-structured interviews, and non-participant \\
& observation \\
Data Analysis & Content Analysis \\
Data processing & Atlas.ti \\
Validity & Validity of content, construct, internal and external validity \\
Reliability & Case study protocol, Field diaries, Review of interviews, Database and Matrix \\
& of theoretical and methodological mooring. \\
\hline
\end{tabular}

Source: Elaborated by the Authors (2018).

\section{DISCUSSION AND ANALYSIS}

Kubíčková, Votoupalová and Toulová (2014) argue that generally in SMEs, the lack of trained personnel, time and resources means that the risk assessment and the management work are conducted intuitively based on the experience of the managers. Although the intuition and experience of business managers are in fact significantly used in the management of breweries, it can be observed that in these enterprises, international activities are mainly 
BBR

16,4

conducted with respect to planning, and the perceived and identified risks throughout the process are treated.

As observed in the interviews, the perceived risks of opening the business and the internationalization processes of the company are supported by the experiences of the entrepreneur and other founding partners. Additionally, being professionals with international experience, taking courses and qualifications outside the country of origin, and participating in trips and fairs in different countries accentuate the international orientation of the business and, with it, the perception that the global activity will be risky is reduced.

According to authors such as Acedo and Jones (2007) and Liesch, Welch and Buckley (2011), different characteristics of the entrepreneurs, such as their international orientations and personal and professional experiences, affect the perceived risks at the moment of internationalization. In the case of the studied craft breweries, it is possible to notice a certain degree of homogeneity in relation to the profile of the founding entrepreneurs of these organizations. Since most of them have an international background, they already had personal or professional experiences abroad. Perhaps for this reason, both the identification of risks and the way that they are perceived present a certain similarity.

As seen in the interviews, the perception about the risk of opening the business and the internationalization processes of the company is supported by the experience of the entrepreneur and the other founding partners. In addition, being professionals with international experience, taking courses and qualifications outside the country of origin and participating in trips and fairs in different countries accentuate the international orientation of the business, and with it, the perception that the international activity will be risky is reduced, assuming that the risk-taking behavior is as described by Jin, Jung and Jeong (2018).

Based on the model that we used and adapted (Figure 1), another factor of analysis emerged after the interviews regarding the classification of the risks and the extent that the interviewees assessed the level of risk among the several factors presented. At various times, respondents stated that monetary risk and country risk are considered as high-risk factors because they are variables external to the organization and thus are not controllable or manageable.

In the interviewees' perceptions, commercial and cultural risk factors can be controlled / managed by the organization. Therefore, these factors belong to a more extensive grouping of "Internal factors" while monetary risk and country risk belong to the grouping of "External factors" in which the company can identify, monitor and react but cannot manage those risks. It can be affirmed at this part of the interview:

"In our view, monetary risk and country risk are the main risks because there is great monetary instability in Brazil and very large government intervention and arbitrariness. Even though you study, we live in a political environment where institutions undermine forecasts. Then, you cannot work with the long-term, and so I put country risk and monetary risk as external factors that are uncontrollable by the organization"(Interviewee 8).

In Figure 1, the factors evaluated by the interviewees during the interviews that are based on the risk classification by Cavusgil, Knight and Riesenberger (2010) were also allocated in the risk-type quadrants. In the interviewees' evaluations, among the risk factors presented by the authors of the international business risk model, the elements highlighted in Figure 1 are the most significantly perceived risk factors in the craft brewery business. 
Figure 1 - The Perception of International Business Risk Classification

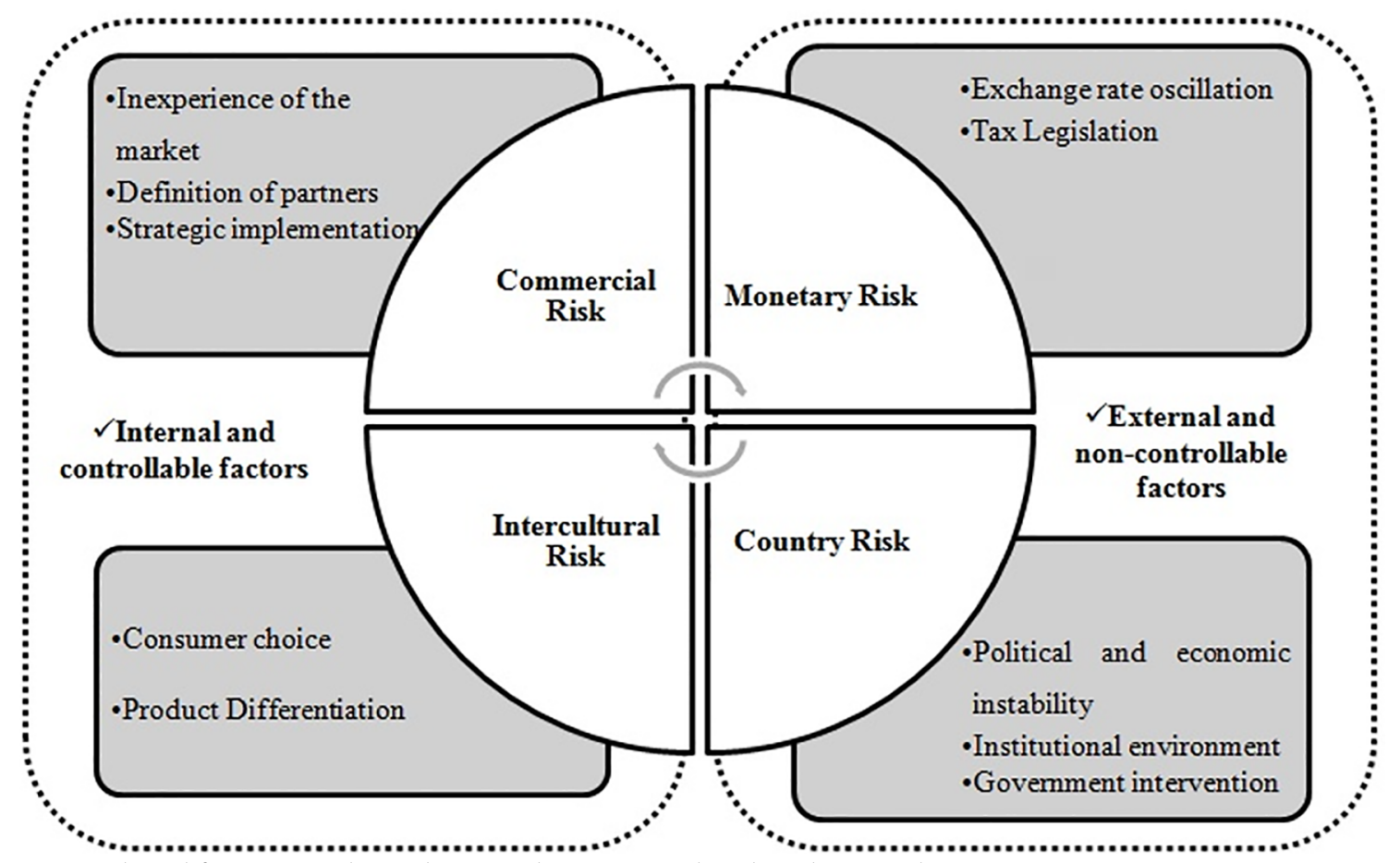

Source: Adapted from Cavusgil; Knight; Riesenberger (2010) based on the research.
BBR

16,4

343

In addition to financial risks, another risk group identified in the international context is the country risk. This grouping refers to the government interventions, the level of bureaucratic activities and corruption, the unfavorable legislation and the social and political instability of some countries (Cavusgil, Kgnith, \& Riesenberger, 2010). As seen in Table 5, at some moments in the interviews, the respondents' statements show that country risk is highly perceived because of Brazil's internal environment, the political instability, and the crisis of trust in governmental institutions and public institutions, which negatively reflects the perception of this type of risk.

During the phase of collecting data on the companies and confirming this information in the interviews, we were able to observe that the identification and evaluation of the country risk have guided the design and growth strategies of several companies. In other words, with the perception that there is instability in the internal environment and with the influence of this perception on the image of the country as it stands in the external environment, some brewery expansion projects have been canceled, and the actions of internationalization had already been programmed, leading to the growth intentions and improvement of some internal processes.

Corroborating this information, Cavusgil and Knight (2015) have already mentioned that governmental factors and the institutional environment can facilitate or hinder the development of international activities, and this outcome is also evident for the brewery sector.

As with the results of this research, Fernandes, Wrubel and Dallabona (2015) and Cortezia and Souza (2011), when analyzing risk management in micro and small Brazilian industries, concluded that risk identification activities and planning actions are the most used by business managers. However, there is no systematic program or evaluation indicators of the risk management system, which is an intuitive activity based on the experience of the managers. 

negotiation, a company from Turkey appears, which does not have economic and politica oes not mean that he will stop buying and he does not say he is not interested. It is just the moment With the country risk, I only obey as long as I can manage the monetary risk. In the risky country, do not control anything. I do not rule the legislation, the bureaucracy, the governmental and the

Source: Research data.

In this sense, even without formal strategies and the systematic actions of risk management, managers must work in a way that protects and creates value for the company (Frigo \& Anderson, 2011). As is shown in the excerpt from interview 3, some actions are taken to avoid further exposure to risk factors, such as the choice of the trading partner and the strategy for entering the foreign market (commercial risks).

"We work with distributors. So, a lot of the exports were sent to a distributor because sending it to the final consumer (pub) would not be worth it, since we concentrated on a good volume with the distributor and he passed it on to the consumer. So, we outsource some risk with this strategy "(Interviewee 3 ).

As presented by Leite and Moraes (2014), the risk factors are analyzed according to the perception of the entrepreneur-manager, and it will be in this context that the actions of the management will be formulated. The more risks there are that managers perceive in the international context and the environment in which they will operate, the more attention will be given, and actions will be taken by the company to mitigate these risks. The problem is not to identify more or fewer risks (Nunes, 2016) but rather to realize that for every type of risky situation, there is a coping action or strategy that can be carried out by the organization (Jin, Jung, \& Jeong, 2018).

In this sense, the most used central actions and strategies of risk mitigation developed by the companies studied are analyzing the environment, studying the sector and researching the market. These analysis and research activities help corporate managers in identifying risks and planning other management actions, such as the structuring of the portfolio of 
international products, the need for strengthening social networks, and the strategy choice of partners and intermediaries, especially in international operations.

According to respondents, an action performed by the companies that has a positive result entails the participation in international missions and festivals. In these events, entrepreneurs strengthen their relationship networks with other companies, distributors and importers in the sector and increase the possibility of the exposure of their products and brands in different markets and with different consumer profiles. With this kind of action, companies seek to minimize the risk of venturing outdoors without having had the approval of the final consumer and without the security and confidence of international partners.

Although it has not been identified in the companies systematized and formal actions for managing risk, it can be concluded that, as noted by authors such as Chiavegatti and Turolla (2011) and Figueira-de-Lemos, Johanson and Vahlne (2011), the mere fact of considering the stages of identification, analysis and classification already indicates a risk management process. That is, by knowing the risk factors that are present in its context, the decisionmaking process and the strategic design will be influenced by these perceptions, and the process of internationalization will likely occur at an accelerated rate, as described in other studies of born global companies.

Rahman, Uddin and Lodorfos (2017) emphasizes the fact that in international ventures, risk factors that are poorly evaluated and managed in domestic operations represent a major concern in the identification and assessment of risks in international business. This notion is perhaps the biggest difference between identifying and managing the risks between domestic enterprises and international enterprises, as in the case of born global companies.

For Jin, Jung and Jeong (2018), companies with international activities will always be involved in larger risk factors, and thus, risk management must be a practice of the enterprise, regardless of its size, along with risk-taking behaviors and considering the degree of risk of internationalization.

Based on the data analysis and the findings of this study, this research intends to contribute by presenting a new integrative model for risk management in born globals

Figure 2 - Risk management integrator model in the process of internationalization for born globals

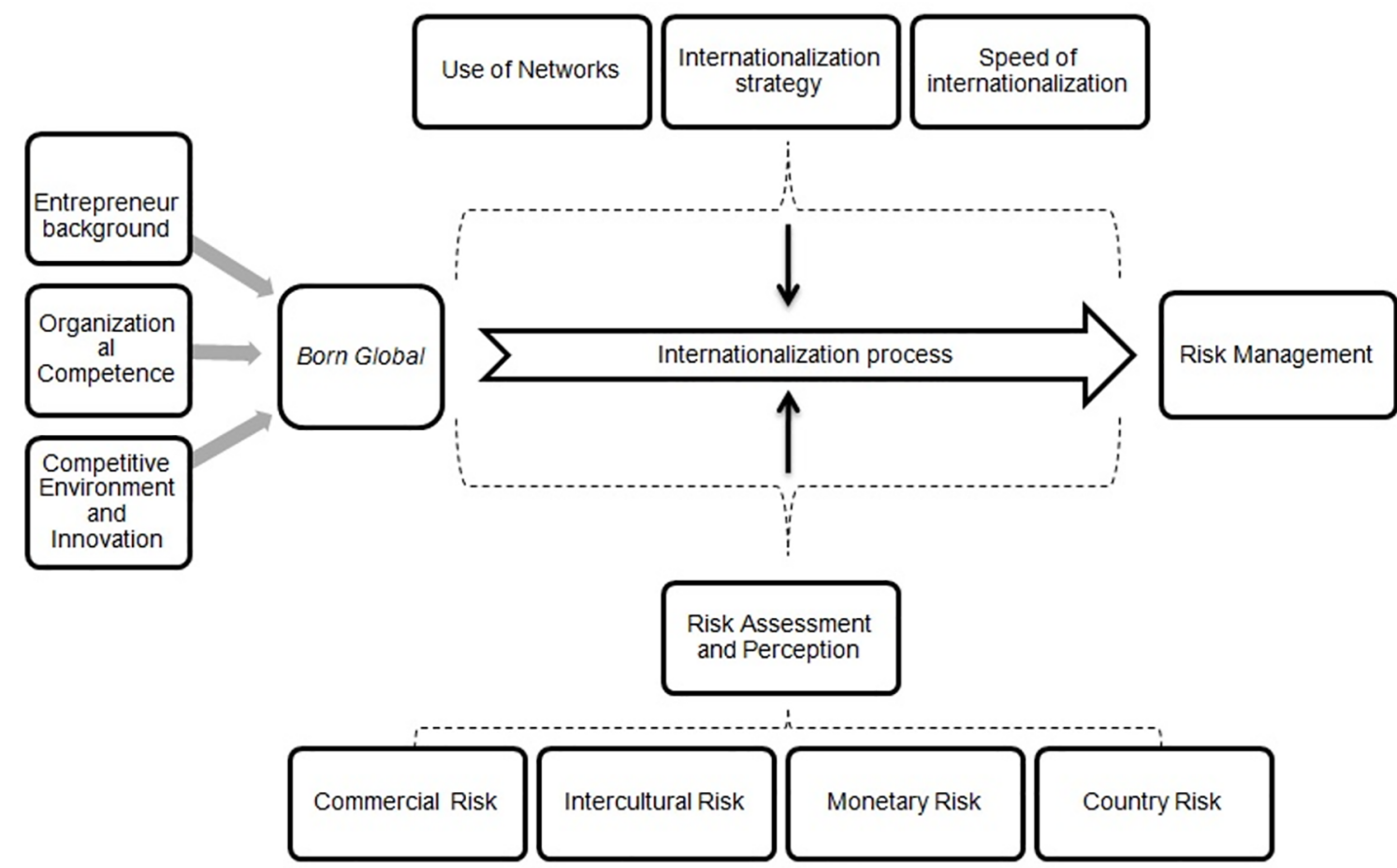

Source: Elaborated by the Authors (2018). 
BBR

16,4
(Figure 2) that is supported by the risk management model in internationalization projects presented by Oviatt, Shrader and McDougall (2004), the research model in the born globals by Madsen and Servais (1997), and the proposed risk classification in international business by Cavusgil, Knight and Riesenberger (2010).

The integrated model (Figure 2) summarizes the phases that were followed during the data analysis of this research by using the analysis pillars of born global companies (Madsen \& Servais, 1997), such as the entrepreneur's background, the organizational competence, the competitive environment and the business innovation. The model also includes the risk factors identified and perceived during internationalization (Cavusgil, Knight, \& Riesenberger, 2010) and considers the classification of risks in international business, commercial, intercultural, monetary and country risk.

In addition to these factors, the integrated model contributed to the evaluation of the three items that were relevant in the internationalization process of the companies studied, such as the use of networks, the choice of internationalization strategies and the speed of the internationalization process. These items that are grouped with the other factors that were already presented have an impact on the internationalization process and how risk management is carried out in these new international ventures.

That is, both the risk management itself and the process of structuring the company's conception, along with the strategies used by the born globals, differ from other ventures (Grazi \& Moschella, 2018). Precisely because of the intention to take on the international risks from the outset of the foundation, we will use different forms of entry in the international market with a greater commitment than if it were to make the process gradual throughout the evolution and growth of the company. This use meets the arguments by Knight and Liesch (2015), Rahman, Uddin and Lodorfos (2017), and Jin, Jung and Jeong (2018), which question the competencies and global risk management practices in born global companies.

\section{FINAL CONSIDERATIONS}

Based on the purpose of analyzing risk managementin the process of the internationalization of born global companies from Brazil, we were able to notice a higher propensity for risk and planning level compared with that of other small traditional enterprises. The view of one of the respondents shows that the interest in entering a highly competitive environment and exploring both the domestic market and the international market demands greater preparation of the projects of born globals. Thus, any desired international activity and being involved in a higher risk level also require a commitment and demand more resources and time in planning.

Concerning the risks involved in the internationalization process of the companies studied, considering the Brazilian context and its institutional and economic environment. More emphasis is given to monetary risk factors, such as the currency fluctuations, tax laws, financial transactions, risk factors, political and economic instability, government interventions, bureaucracy and even the institutional environment related to the country. In addition to these risks, commercial and cross-cultural risk factors were also identified, but, in the opinion of entrepreneurs, these risks exert less influence on the strategies and decision-making processes of these organizations.

Based on this research, we can still say that, with respect to the development of born globals from emerging countries, some risk factors differ from other international enterprises from developed countries, particularly the monetary risk factors and country risk, which are due to the structuring of the institutional environment, the regulation of the domestic market and the economic and political situations of the countries of origin, as already indicated in recent studies carried out by Monticelli (2017) and Yaprak, Yosun and Cetindamar (2018). 
Gabrielsson et al. (2008) and Jin, Jung and Jeong (2018) argue that, with respect to risk management, the ways that risks are perceived and managed in born globals differ from the other projects. Therefore, we believe that what is differentiated in this research is how skills and entrepreneurial skills influence risk perception. Furthermore, through different strategies, such as environmental analysis, extensive market research, planning and scenario building and use of networks, managers can address the possible risks involved in international operations.

\subsection{IMPLiCATIONS AND CONTRIBUTIONS}

Based on the data analysis and discussion of the results, some contributions and new questions are raised as a contribution of the results of this research. First, born global companies, due to the international backgrounds of the entrepreneurs, have relationships with different social networks, and fewer risks in international business are perceived; thus, there is a greater commitment to, and involvement with, the process of internationalization. Second, the risk factors in born globals differ from the risk factors of traditional small businesses to the extent that risk analysis is carried out in the internal environment and the external environment, and being exposed to the latter ends up being influenced by different risks.

The integrative model presented in this research contributes to the evaluation of the three items that were relevant in the internationalization process of the companies studied, such as the use of networks, the choice of internationalization strategies and the speed of the internationalization process. These items were grouped with the other factors that already presented impacts on the internationalization process and how risk management is carried out in these new international ventures.

In addition to the contributions and discussion raised in this paper, we believe it is essential for future research to understand the construction of the relationship of global networks in international developments, how these relationships influence the degree of internationalization of born globals and the perception of risk in international activities.

The relevance and lack of business studies in born globals of different sectors, such as industries and services, remain to be addressed. In addition to the works already done on technology companies, the research must also address how being in different environments can develop different characteristics in terms of its rapid international development and if there are differences in the way that the risks of global operations are managed in these various sectors.

\section{REFERENCES}

Acedo, F. J., \& Florin, J. (2006). An entrepreneurial cognition perspective on the internationalization of SMEs. Journal of International Entrepreneurship, 4(1), 49-67.

Acedo, F. J., \& Jones, M. V. (2007). Speed of internationalization and entrepreneurial cognition: Insights and the comparison between international new ventures, exporters and domestic Firms. Journal of World Business, 42(3), 236-252.

Andersson, U., Johanson, J., \& Vahlne, J. E. (1997). Organic acquisitions in the internationalization process of the business firm. MIR: Management International Review, 37, 67-84.

Autio, E. (2017). Strategic entrepreneurial internationalization: A normative framework. Strategic Entrepreneurship Journal, 11(3), 211-227.

Bardin, L. (2006). Analysis content. Oxford: Oxford University Press.

Bartlett, C. A., \& Ghoshal, S. (2000). Going Global: Lessons from late movers. Harvard Business Review, $78(2), 132-142$.

Boso, N., Oghazi, P., \& Hultman, M. (2017). International entrepreneurial orientation and regional expansion. Entrepreneurship \& Regional Development, 29(1-2), 4-26.

Buckley, P. J., \& Casson, M. (1976). The Future of the Multinational Enterprise. London: Macmillan. 
BBR

16,4
Cahen, F. R., Oliveira, M. M., Jr., \& Borini, F. M. (2017). The internationalisation of new technology-based firms from emerging markets. International Journal of Technology Management, 74(1-4), 23-44.

Cavusgil, S. T., \& Knight, G. (2015). The born global firm: An entrepreneurial and capabilities perspective on early and rapid internationalization. Journal of International Business Studies, 46(1), 3-16.

Cavusgil, T. S., Knight, G. A, \& Riesenberger, J. R. (2010). Negócios Internacionais: estratégia, gestão e novas realidades. São Paulo: Pearson.

Chiavegatti, D., \& Turolla, F. A. (2011). Risco no Modelo de Internacionalização de Uppsala. Revista Organizações em Contexto, 7(13), 129-156.

Choquette, E., Rask, M., Sala, D., \& Schröder, P. (2017). Born Globals-Is there fire behind the smoke? International Business Review, 26(3), 448-460.

Cortezia, S. L. D., \& Souza, Y. S. de (2011). An analysis of the internationalization of small Brazilian software companies. Brazilian Business Review, 8(4), 23-43.

Dib, L. A., Rocha, A. da, \& Silva, J. F. (2010). The internationalization process of Brazilian software firms and the born global phenomenon: Examining firm, network, and entrepreneur variables. Journal of International Entrepreneurship, 8(3), 233-253.

Dimitratos, P., Johnson, J. E., Plakoyiannaki, E., \& Young, S. (2016). SME internationalization: How does the opportunity-based international entrepreneurial culture matter? International Business Review, 25(6), 1211-1222.

Dzikowski, P. (2018). A bibliometric analysis of born global firms. Journal of Business Research, 85, 281294.

Dunning, J. H. (1979). Explaining changing patterns of international production: in defense of the ecletic theory. Oxford Bulletin of Economics and Statistics, 41(4), 269-295.

Eisenhardt, K. M. (1989). Building theories from case study research. Academy of Management Review, $14(4), 532-550$.

Fernandes, F. C., Wrubel, F., \& Dallabona, L.F. (2015). Gerenciamento de riscos na cadeia de suprimentos de micro e pequenas empresas têxteis: discussão exploratória sobre oportunidades de pesquisa. $R E G E P E-$ Revista de Empreendedorismo e Gestão de Pequenas Empresas, 4(1), 125-151.

Figueira-de-Lemos, F., Johanson, J., \& Vahlne, J. E. (2011). Risk management in the internationalization process of the firm: A note on the Uppsala model. Journal of World Business, 46(2), 143-153.

Frigo, M. L. (2009). Strategic Risk Management: The New Core Competency. "Balanced Scorecard Report", No. 1, January-February.

Frigo, M. L., \& Anderson, R. J. (2011). Strategic risk management: A foundation for improving enterprise risk management and governance. Journal of Corporate Accounting \& Finance, 22(3), 81-88.

Gabrielsson, M., Kirpalani, V. M., Dimitratos, P., Solberg, C. A., \& Zucchella, A. (2008). Born globals: Propositions to help advance the theory. International Business Review, 17(4), 385-401.

Grazzi, M., \& Moschella, D. (2018). Small, young, and exporters: New evidence on the determinants of firm growth. Journal of Evolutionary Economics, 28(1), 125-152.

Grichnik, D. (2008). Risky choices in new venture decisions - experimental evidence from Germany and the United States. Journal of International Entrepreneurship, 6(1), 22-47.

Hånell, S. M., Nordman, E. R., \& Tolstoy, D. (2017). New product development in foreign customer relationships: a study of international SMEs. Entrepreneurship \& Regional Development, 29(7-8), 715734.

Hymer, S. H. (1976). The International Operations of National Firms: A Study of Direct Foreign Investment. Cambridge: The MIT Press.

Jin, B., Jung, S., \& Jeong, S.W. (2018). Dimensional effects of Korean SME's entrepreneurial orientation on internationalization and performance: the mediating role of marketing capability. International Entrepreneurship and Management Journal, 14(1), 195-215.

Johanson, J., \& Vahlne, J. E. (1977). The internationalization process of the firm-a model of knowledge development and increasing foreign market commitments. Journal of international business studies, 8(1), 23-32.

Knight, G. A., \& Cavusgil, S. T. (2004). Innovation, organizational capabilities, and the born-global firm. Journal of International Business Studies, 35(2), 124-141.

Knight, G. A., \& Liesch, P. W. (2015). Internationalization: From incremental to born global. Journal of World Business, 51(1), 93-102.

Kubíčková, L., \& Toulová, M. (2013). Risk factors in the internationalization process of SMEs. Acta Universitatis Agriculturae et Silviculturae Mendelianae Brunensis, 61(7), 2385-2392. 
Kubíčková, L., Tuzová, M., \& Toulová, M. (2016). The internationalisation of small and medium-sized enterprises as a path to competitiveness. In P. Huber, D. Nerudová, \& P. Rozmahel (Eds.). Competitiveness, Social Inclusion and Sustainability in a Diverse European Union (pp. 99-120). Switzerland: Springer International Publishing.

Kubíčková, L., Votoupalová, M., \& Toulová, M. (2014). Key motives for internationalization process of small and medium-sized enterprises. Procedia Economics and Finance, 12, 319-328.

Leite, W. F. V. P., \& Moraes, Y. A. (2014). Facetas do risco no empreendedorismo internacional. RAC-Revista de Administração Contemporânea, 18(1), 96-117.

Liesch, P. W., Welch, L. S., \& Buckley, P. J. (2011). Risk and uncertainty in internationalization and international entrepreneurship studies. Management International Review, 51(6), 851-873.

Madsen, T. K., \& Servais, P. (1997). The internationalization of born globals: an evolutionary process? International Business Review, 6(6), 561-583.

March, J. G., \& Shapira, Z. (1987). Managerial perspectives on risk and risk taking. Management Science, 33(11), 1404-1418.

Miller, K. D. (1992). A framework for integrated risk management in international business. Journal of international business studies, 23(2), 311-331.

Miles, M. B., \& Huberman, A. M. (1994). Qualitative data analysis: An expanded sourcebook. Thousand Oaks: Sage Publications.

Monticelli, J. M., Calixto, C. V., Vasconcellos, S. L. D., \& Garrido, I. L. (2017). The influence of formal institutions on the internationalization of companies in an emerging country. Revista Brasileira de Gestão de Negócios, 19(65), 358-374.

Nunes, M. P. (2016). Motivations, risks, barriers, and results associated with the adoption of global sourcing by brazilian companies: A case-based study. Brazilian Business Review, 13(2), 135-157.

Oviatt, B. M., \& McDougall, P. P. (2005). Toward a theory of international new ventures. Journal of International Business Studies, 25(1), 45-64.

Oviatt, B. M., Shrader, R. C., \& McDougall, P. P. (2004). The internationalization of new ventures: The risk management model. In M. A. Hitt \& J. L. C. Cheng (Eds.). Theories of the Multinational Enterprise: Diversity, Complexity and Relevance. Advances in International Management (Vol. 16, pp. 165-185). Amsterdam: Elsevier.

Rahman, M., Uddin, M., \& Lodorfos, G. (2017). Barriers to enter in foreign markets: evidence from SMEs in emerging market. International Marketing Review, 34(1), 68-86.

Rodriguez, V., Boats, L., \& Alvarez, M. J. (2010). Managing risk and knowledge in the internationalization process. Intangible Capital, 6(2), 202-235.

Sitkin, S. B., \& Weingart, L. R. (1995). Determinants of risky decision-making behavior: A test of the mediating role of risk perceptions and propensity. Academy of Management Journal, 38(6), 1573-1592.

Sozuer, A., Altuntas, G., \& Semercioz, F. (2017). International entrepreneurship of small firms and their export market performance. European Journal of International Management, 11(3), 365-382.

Telles, R. (2001). A efetividade da matriz de amarração de Mazzon nas pesquisas em Administração. Revista de Administração da Universidade de São Paulo, 36(4), 64-72.

Trudgen, R., \& Freeman, S. (2014). Measuring the performance of born-global firms throughout development their process: The roles of initial market selection and internationalization speed. Management International Review, 54(4), 551-579.

Vernon, R. (1966). International Investments and international trade in the product cycle. Quarterly Journal of Economics, 80(2), 190-207.

Weerawardena, J., Mort, G. S., Liesch, P. W., \& Knight, G. (2007). Conceptualizing accelerated internationalization in the born global firm: The dynamic capabilities perspective. Journal of World Business, 42(3), 294-306.

Yaprak, A., Yosun, T., \& Cetindamar, D. (2018). The influence of firm-specific and country-specific advantages in the internationalization of emerging market firms: Evidence from Turkey. International Business Review, 27(1), 198-207. 